\title{
Erratum
}

\section{Unveiling the ambrotype: characterization of two 19th century photographs-ERRATUM}

Leonor Costa, Margarida Nunes, Sónia Costa, Milene Trindade, Catarina Miguel and Teresa Ferreira

doi:10.1017/S1431927618000429, Published by Cambridge University Press, 2 August 2018

In the original publication, the text "Q2-Q3" on page 3 was inserted in error during proof revision. The publisher apologizes for the error.

\section{Reference}

Costa L, Nunes M, Costa S, Trindade M, Miguel C, Ferreira T (2018) Unveiling the Ambrotype: Characterization of Two 19th Century Photographs. Microsc Microanal 25, 203-213. 